\title{
The Specifics of Understanding the Information from Different Types of Mass Media by Young People
}

\section{Особливості розуміння молодими людьми новинної інформації з різних типів ЗМК}

\author{
Elena Medvedskaia \\ Ph.D. in Psychology, Assistant Professor, Brest State A.S. Pu- \\ shkin University, Brest (the Republic of Belarus) \\ ORCID ID: https://orcid.org/0000-0003-2033-510X \\ Researcher ID: http://www.researcherid.com/rid/M-4006-2019 \\ E-mail: EMedvedskaja@mail.ru

\section{Елена Медведская} \\ Кандидат психологічних наук, доцент, Брестський держав- \\ ний університет імені О.С. Пушкіна, м. Брест (Білорусь)
}

\section{ABSTRACT}

The aim of the article is to establish the specifics of understanding local and world news from different sources by young people (Internet portals, social networks, TV, the press).

Methods. The study involved 200 students aged from 17 to 23 (female, $n=120$ and male, $n=80$ ). The empirical research intended to solve three tasks. The first task is to model a hierarchy of media according to two criteria: frequency of usage and a degree of trust. We solved this task via a ranking method and a correlation analysis of the data. The second task, to analyze the ideas of young people about the characteristics of information from different media, was reached through an author's version of a semantic differential. The third task, to establish categories of consciousness that mediate the understanding of

Address for correspondence, e-mail: kpnu_lab_ps@ukr.net Copyright: (C) Medvedskaia Elena

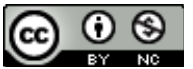

The article is licensed under CC BY-NC 4.0 International

(https://creativecommons.org/licenses/by-nc/4.0/)

(C) Medvedskaia Elena

DOI (article): https://doi.org/10.32626/2227-6246.2021-53.173-190 
DOI: https://doi.org/10.32626/2227-6246.2021-53

2021. випуск 53

the information, was implemented through factorization of the data of semantic differential.

Results of the research. We established that young people demonstrate maximum trust to the information from Internet portals, social networks and through direct informal communication. They demonstrate the lowest degree of trust towards the messages from representatives of the administration, TV and the press. Comparative analysis revealed statistically significant differences among the profiles $(p \leq 0.01)$, apart from the information from the Internet portals and the press. We established number of categories that mediate the understanding of the information, demonstrate a more complex cognitive formation of consciousness regarding digital media. The content of the leading categories appeared to be statistically identical.

Conclusions. The study revealed a direct correlation between the level of trust and a degree of officiality of the source. Young people demonstrate higher degree of trust to unofficial sources and less trust to official sources. According to young people's perception, information from the Internet portals affects their cognitive sphere while social networks and TV touch the emotional. A common feature of the news from digital and printed media is a highly competent approach to the creation of the content. Undifferentiated content of the categories proves poor understanding of its nature and the relevance of efforts to develop the independence and critical thinking of young people.

Key words: mass media, information, young people, degree of trust, categories of consciousness.

\section{Introduction}

A diversity of the information sources is one of the most essential aspects of the modern information society. The Internet has undoubted advantages in comparison with traditional media (the press and TV), e.g. an update rate, a variety of encryption methods, a level of self involvement in the content of interest and demonstration of one's own opinion on current events.

Naturally, representatives of the generation $\mathrm{Z}$, the one who has had access to the Internet from a young age, prefer the Internet to other media. Despite all the benefits of the Internet, there is one essential drawback - open access to infor(C) Medvedskaia Elena

DOI (article): https://doi.org/10.32626/2227-6246.2021-53.173-190 
mation of any kind. Therefore, the problem of an impact of the Internet on a user becomes an object of psychological studies more and more often. The studies on this problem are mainly of two kinds. The first is the theoretical and empirical study on psychological safety of the Internet information for the users of different age groups (Aysina, 2019; Kirillov \& Solovyeva, 2020; Ovcharenko, 2017; Chusavitina, Davletkireeva \& Novikova, 2016, etc.). In the second group, an object of the research is a potential destructive and propaganda manipulation of a person (Gorbunov, 2016; Krinickiy, 2019; Salikhov \& Krasnoshchechenko, 2020; Zhang et al., 2013, etc.)

A comparative analysis of information impact from different sources might be another perspective direction for the research. It would help to establish the specifics of Internet impact on the recipient. There are few researches in this field at the moment. For example, a group of Russian psychologists compare public discourse on pension reform in official publications and on the Internet in their study (Drobysheva, Yemelyanova, Drobysheva \& Shmidt, 2019). The authors used publications devoted to an employment problem from the newspaper «Trud» and the content from the Internet forums. They revealed a number of differences with an emotional-lexical analysis of the texts. The most significant difference was the nature of the information. In most cases, the press interpreted the reform, and the analysis appealed to the rationality of a recipient. Meanwhile, Internet forums were a platform to express negative emotions. Thus the results of the research show that different media can produce opposite content regarding the same event. The explanation is in the degree of officiality of the sources.

There are numerous interpretations of local and world events in different mass media. This knowledge is important for several reasons. One of them is a regulation of behaviour of young people as the most socially-active category of the popu-

C Medvedskaia Elena

DOI (article): https://doi.org/10.32626/2227-6246.2021-53.173-190 
DOI: https://doi.org/10.32626/2227-6246.2021-53

2021. випуск 53

lation which is in the process of cyber socialization (Onufriieva, Didyk \& Chekanska, 2019). Another reason is modelling a worldview of people of a new formation. The reasons mentioned above determine the actuality of the research of understanding the information from different mass media by young people.

\section{Object of the article}

An object of the article is to establish the specifics of understanding local and world news from different sources by young people (Internet portals, social networks, TV, the press).

\section{Materials and Methods}

The study (voluntarily and anonymously) involved 200 students of 1-4 courses from different faculties of Brest State A.S. Pushkin University. The participants included 120 females and 80 males aged from 17 to 23. The collecting of empirical data was carried out throughout 2020.

The empirical research was to achieve several tasks:

1. To establish the hierarchy of media according to two criteria: frequency of usage and degree of trust. To realize this task, we used a ranking method. The students got a list of the most popular types of media. Primary processing of the data comprised calculating the arithmetic average rank of each source, secondary one was carrying out a correlation analysis of the average profiles estimates.

2. To analyze the ideas of young people about the characteristics of information from different media. We used the author's variant of a semantic differential method. As descriptors we used 30 characteristics of information presented in various dictionaries. The students evaluated the information about current events from different media according to the unipolar scales. Data processing comprised constructing averaged profiles for each source and subsequently comparing them.

(C) Medvedskaia Elena

DOI (article): https://doi.org/10.32626/2227-6246.2021-53.173-190 
DOI: https://doi.org/10.32626/2227-6246.2021-53

2021. випУСК 53

3 . To reconstruct the categories of consciousness that mediate the understanding of the information by young people. The initial empirical material was data of the semantic differential (Petrenko, 2005: 91, 98, 191, 225): a centroid method with an extraction of the main components that included a varimax rotation (program SPSS v. 16). Only the descriptors which had a high degree of statistical significance were used to form the factor (for 30 variables $r=0.36$ for $p \leq 0.05$ and $\mathrm{r}=0.47$ for $\mathrm{p} \leq 0.01)$.

\section{Results and Discussion}

Table 1 presents averaged profiles of different information sources. The data is obtained by ranking ( 1 is the highest and 7 is the lowest).

Table 1

Results of ranking of the information sources

\begin{tabular}{|l|c|c|c|c|}
\hline \multirow{2}{*}{\multicolumn{1}{c|}{ Information source }} & \multicolumn{4}{c|}{ Ranking criteria } \\
\cline { 2 - 5 } & \multicolumn{2}{|c|}{$\begin{array}{c}\text { Frequency } \\
\text { of usage }\end{array}$} & \multicolumn{2}{c|}{ Degree of trust } \\
\cline { 2 - 5 } & M & Rank & M & Rank \\
\hline The press & 2.04 & 7 & 3.31 & 7 \\
\hline TV (local) & 3.06 & 5 & 3.26 & 8 \\
\hline TV (foreign) & 3.11 & 4 & 3.42 & 4 \\
\hline Radio & 2.44 & 6 & 3.36 & 5 \\
\hline Internet Portals & 5.86 & 2 & 5.18 & 1 \\
\hline Social Networks & 6.02 & 1 & 4.63 & 3 \\
\hline $\begin{array}{l}\text { Other people (relatives, friends, } \\
\text { etc.) }\end{array}$ & 5.42 & 3 & 5.05 & 2 \\
\hline $\begin{array}{l}\text { Representatives of the } \\
\text { administration }\end{array}$ & 2.02 & 8 & 3.38 & 6 \\
\hline
\end{tabular}

Data from Table 1 prove that digital media are the most frequently used by young people (primarily social networks

C Medvedskaia Elena

DOI (article): https://doi.org/10.32626/2227-6246.2021-53.173-190 
DOI: https://doi.org/10.32626/2227-6246.2021-53

2021. випуск 53

and news Internet portals), as well as information through communication with other people. The least used sources are the radio (the usage is occasional either in a car or during the visit to the older generation), the press and representatives of the administration. Thus, in terms of frequency of usage, digital media and informal communication get the leading positions.

Regarding a degree of trust, the positions are as follows in descending order: Internet portals (tut.by, onliner.by, etc.), informal direct communication and social networks. Even though social networks are frequently used source of information among young people, a degree of trust in its content is lower than in specialized portals or people they know. The main reason for a decrease in trust might be one's self experience that proves a possibility of falsifying the information (e.g. Photoshop). Probably, the information from social networks goes through so-called check up through the comparison with opinions from the Internet portals and interpretation by competent people.

According to the answers, the least trustworthy sources are representatives of the administration, the press, and local TV channels. A common feature of these three sources is a high degree of officiality. This fact determines the specifics of the selection, presentation and interpretation of messages under the ideological guidelines that are currently socially approved.

There is a direct but not strongly pronounced correlation between frequency of usage and a degree of trust to the source $(\mathrm{r}=0.76, \mathrm{r}=0.72$ for $\mathrm{p} \leq 0.05$ and $\mathrm{r}=0.72$ for $\mathrm{p} \leq 0.05)$.

Therefore, it is advantageous to limit the study with the sources which have extreme points of the degree of trust: maximum (Internet portals and social networks) and minimum (TV and periodicals). The data in Table 2 sums up the results of the analysis of the ideas of the students about the characteristics of information from different media.

(C) Medvedskaia Elena

DOI (article): https://doi.org/10.32626/2227-6246.2021-53.173-190 
Averaged profiles of the information from different types of media

\begin{tabular}{|l|l|c|c|c|c|}
\hline № & \multicolumn{1}{|c|}{$\begin{array}{c}\text { Characteristics } \\
\text { of the information }\end{array}$} & $\begin{array}{c}\text { Internet } \\
\text { portals }\end{array}$ & $\begin{array}{c}\text { Social } \\
\text { networks }\end{array}$ & TV & $\begin{array}{c}\text { News- } \\
\text { papers }\end{array}$ \\
\hline 1 & Fast & 6.28 & 6.12 & 4.2 & 3.11 \\
\hline 2 & Complex & 3.56 & 3.48 & 3.92 & 4.09 \\
\hline 3 & Structured & 5.28 & 4.50 & 4.29 & 5.09 \\
\hline 4 & Analytical & 4.62 & 4.13 & 4.46 & 4.62 \\
\hline 5 & Real & 5.13 & 4.63 & 4.28 & 4.16 \\
\hline 6 & Qualified & 4.8 & 4.00 & 4.91 & 5.03 \\
\hline 7 & Comprehensive & 4.81 & 4.54 & 3.91 & 4.37 \\
\hline 8 & True & 5.01 & 4.56 & 4.04 & 4.23 \\
\hline 9 & Secret & 3.36 & 3.31 & 3.09 & 2.92 \\
\hline 10 & Brief & 4.72 & 4.67 & 3.85 & 4.01 \\
\hline 11 & Informative & 5.32 & 4.72 & 4.56 & 4.78 \\
\hline 12 & High quality & 4.95 & 4.25 & 4.44 & 4.38 \\
\hline 13 & Useful & 5.6 & 5.22 & 4.36 & 4.16 \\
\hline 14 & Full & 5.29 & 5.01 & 3.96 & 4.27 \\
\hline 15 & Prompt & 5.94 & 5.78 & 5.34 & 4.25 \\
\hline 16 & Contradictive & 4.65 & 4.67 & 4.1 & 4.07 \\
\hline 17 & Essential & 5.15 & 4.70 & 4.4 & 4.15 \\
\hline 18 & Poor & 3.44 & 3.27 & 3.9 & 4.18 \\
\hline 19 & Objective & 4.9 & 4.56 & 3.9 & 4.18 \\
\hline 20 & Inducing to the conclusions & 5.55 & 5.18 & 3.36 & 4.39 \\
\hline 21 & Inducing to the actions & 5.17 & 4.90 & 3 & 3.50 \\
\hline 22 & Raw & 3.79 & 4.14 & 3 & 2.67 \\
\hline 23 & Descriptive & 5.32 & 5.10 & 4.45 & 4.66 \\
\hline 24 & Critical & 4.53 & 4.31 & 3.76 & 3.53 \\
\hline 25 & Accurate & 4.87 & 4.31 & 4.04 & 4.20 \\
\hline 26 & Verified & 4.54 & 4.25 & 4.4 & 4.47 \\
\hline 27 & Negative & 4.52 & 4.64 & 4.12 & 4.01 \\
\hline
\end{tabular}

(c) Medvedskaia Elena 
DOI: https://doi.org/10.32626/2227-6246.2021-53

2021. випуск 53

\begin{tabular}{|l|l|c|c|c|c|}
\hline № & \multicolumn{1}{|c|}{$\begin{array}{c}\text { Characteristics } \\
\text { of the information }\end{array}$} & $\begin{array}{c}\text { Internet } \\
\text { portals }\end{array}$ & $\begin{array}{c}\text { Social } \\
\text { networks }\end{array}$ & TV & $\begin{array}{c}\text { News- } \\
\text { papers }\end{array}$ \\
\hline 28 & Blank & 3.36 & 3.97 & 3.63 & 3.71 \\
\hline 29 & Reliable & 4.72 & 4.08 & 3.96 & 4.20 \\
\hline 30 & Scandalous & 5.11 & 5.26 & 4.68 & 4.29 \\
\hline
\end{tabular}

According to the data in Table 2, young people find news from digital media at most fast (1) and prompt (15). Information from Internet portals encourages thinking (20) while information from social networks arises vivid emotions (30). Information from TV has similar characteristics to the one from social networks: prompt (15) and scandalous (30). Unlike social networks, TV news producers are more qualified (6). Information from the periodicals is highly rated as structured (3), qualified (6), and informative (11).

A comparison of the profiles shows that the characteristics of the information from Internet portals and social networks $(t=5.71$ with a critical $t=2.71$ for $p \leq 0.05)$ differ from the one from the Internet portals and TV( $t=5.6)$. Meanwhile, there is not much difference between profiles of Internet portals and the press $(t=1.19)$. According to the respondents, the information from these types of media possesses the characteristics of qualified, verified information like structured (3), analytical (4), accurate (25) etc. In young people's view, information from the Internet is not only faster (1) and more prompt (15), but also has a certain power to transform the thinking and behaviour of the recipients $(21,22)$.

We have established the categories of consciousness that mediated the understanding of information by young people. Under the Kaiser's selection criterion, different types of media have a different number of categories: Internet portals - 9, social networks -10 , TV and the periodicals -8 each. This fact demonstrates a greater cognitive complexity of information from digital media in young people's minds. It is fully consistent with their experience of using different media (Table 1). (C) Medvedskaia Elena

DOI (article): https://doi.org/10.32626/2227-6246.2021-53.173-190 
DOI: https://doi.org/10.32626/2227-6246.2021-53

2021. ВИПУСК 53

Table 3 reflects the content of three leading categories for each type of media, since most of identified categories have very low subjective significance (the percentage of variance does not exceed the randomness threshold).

Table 3

Categorical structure of information from different media in the consciousness of young people

\begin{tabular}{|c|c|c|c|c|}
\hline & \multicolumn{2}{|c|}{ Internet portals } & \multicolumn{2}{|c|}{ Social networks } \\
\hline \multirow[t]{13}{*}{1} & \multicolumn{2}{|c|}{$\begin{array}{c}\text { «Positive assessment» } \\
(27.05 \%)\end{array}$} & \multicolumn{2}{|c|}{$\begin{array}{c}\text { Positive assessment» } \\
(26.75 \%) \\
\end{array}$} \\
\hline & real & 0.795 & accurate & 0.802 \\
\hline & objective & 0.745 & objective & 0.764 \\
\hline & structured & 0.735 & true & 0.762 \\
\hline & analytical & 0.698 & reliable & 0.760 \\
\hline & essential & 0.664 & verified & 0.696 \\
\hline & true & 0.625 & real & 0.677 \\
\hline & reliable & 0.606 & high quality & 0.661 \\
\hline & accurate & 0.603 & useful & 0.573 \\
\hline & verified & 0.565 & essential & 0.562 \\
\hline & high quality & 0.532 & comprehensive & 0.546 \\
\hline & informative & 0.511 & full & 0.523 \\
\hline & & & analytical & 0.469 \\
\hline \multirow[t]{6}{*}{2} & \multicolumn{2}{|c|}{$\begin{array}{c}\text { «Impact strength» } \\
(9.75 \%)\end{array}$} & \multicolumn{2}{|c|}{$\begin{array}{c}\text { «Impact strength» } \\
(9.77 \%)\end{array}$} \\
\hline & prompt & 0.763 & inducing to the & 0.792 \\
\hline & inducing to the & 0.752 & actions & \\
\hline & conclusions & & scandalous & 0.773 \\
\hline & inducing to the actions & 0.737 & prompt & 0.632 \\
\hline & & & $\begin{array}{l}\text { inducing to the } \\
\text { conclusions }\end{array}$ & 0.610 \\
\hline \multirow[t]{4}{*}{3} & \multicolumn{2}{|c|}{ «Activity» (6.93\%) } & \multicolumn{2}{|c|}{$\begin{array}{c}\text { «Negative assessment» } \\
(7.46 \%)\end{array}$} \\
\hline & useful & 0.658 & negative & 0.803 \\
\hline & fast & 0.655 & contradictive & 0.695 \\
\hline & full & 0.653 & blank & 0.532 \\
\hline
\end{tabular}

(C) Medvedskaia Elena 


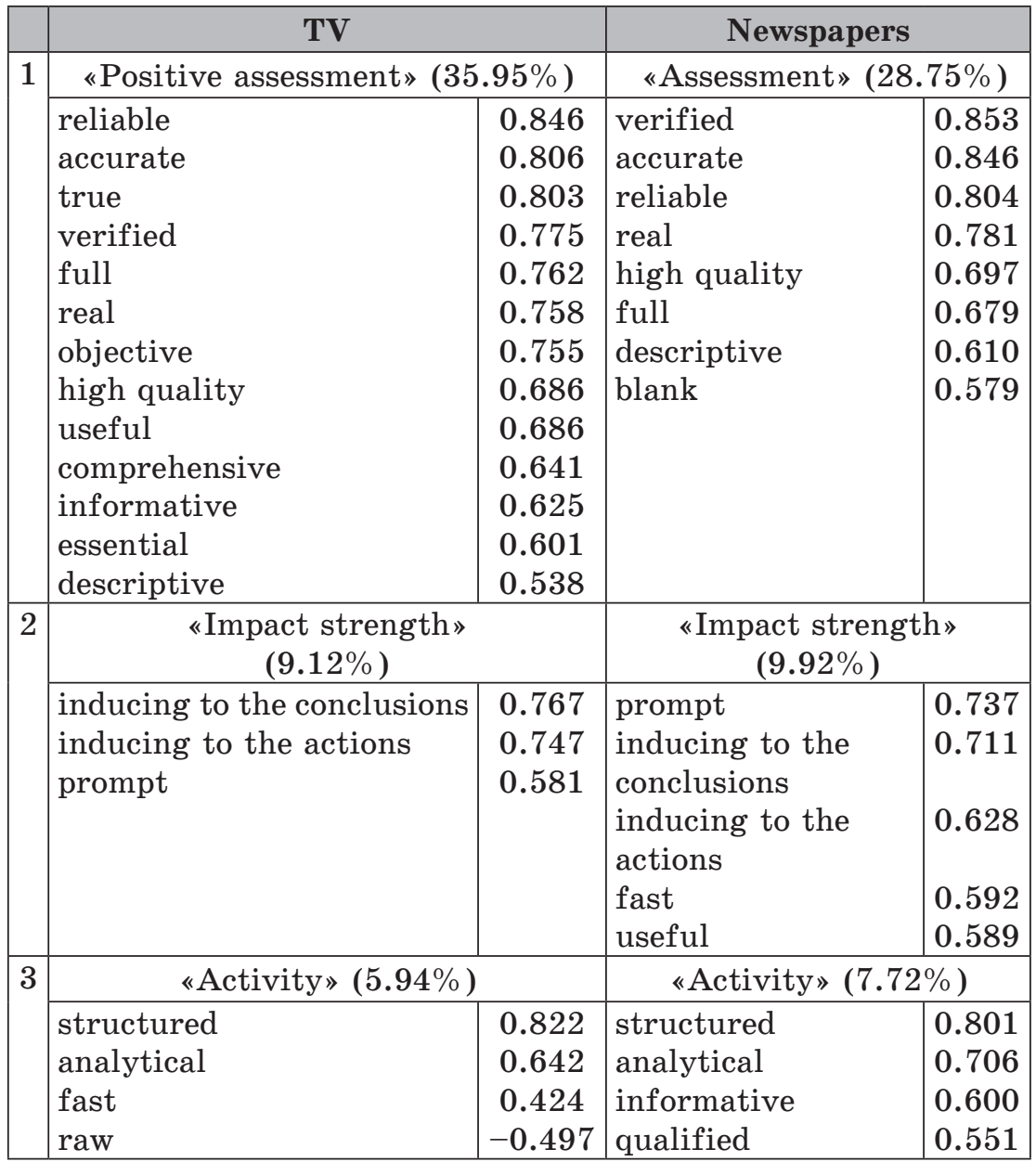

Their titles are as close as possible to the universal categories of consciousness: Assessment, Strength and Activity (Osgood, Suci \& Tannenbaum, 1957). There is a percentage of the factor variance next to the category title, and opposite to the descriptors there is their statistical load by the factor ( $\mathrm{p} \leq 0.01)$.

\section{(C) Medvedskaia Elena}

DOI (article): https://doi.org/10.32626/2227-6246.2021-53.173-190 
Horizontal analysis of the data in Table 3 demonstrates a high level of equality of the categories. First factor includes various features of information: objectivity, trustworthiness, completeness, etc., as well as its types (descriptive and analytical). The only difference is in the category that reflects a factorization of information from the press. It has less content and a more complex internal organization presented with two poles «accurate-blank». That is why it got a more general title «Assessment».

The second category is more homogenous according to its leading descriptors. Young people interpret the power of the information mainly as its influence on the recipient's thinking and behaviour $(20,21)$, and its relevance (15).

The content of the third category, equal to the universal category "Activity", is different for all the media. Regarding the Internet portals, an emphasis is on their technological capabilities (transmission speed and pluralism of points of view). For TV and the newspapers, the activity of the information associated with the activity of the creators who work on the content and presentation. The information from social networks comprises negative characteristics in the minds of the respondents, therefore, it is designated as «Negative assessment» in Table 3.

\section{Conclusions}

Young people prefer digital media (social networks and Internet portals) and information got through informal communication. These sources are the most trustworthy according to the analysis. The least trustworthy sources are official information (TV, newspapers, representatives of the administration). A correlation between a degree of trust and officiality of the source might be considered as a manifestation of a psychological peculiarity of this age group, the youth nonconformism, in the modern reality of a digital society.

CC Medvedskaia Elena

DOI (article): https://doi.org/10.32626/2227-6246.2021-53.173-190 
DOI: https://doi.org/10.32626/2227-6246.2021-53

2021. випУСК 53

A relation between frequency of usage and a degree of trust to its contents is direct, though statistically not highly pronounced. Such a correlation proves the existence of a gap between usage of the source and interpreting its contents. Probably, it is this gap that makes it possible to organize a «zone of proximal development» for the development of independence and critical thinking of users.

The perception of young people of the information from the different media (Internet portals, social networks, TV) is significantly different. The fundamental difference is in «the sphere of influence of information" or "the sphere of the recipient's response». Specifically, information from Internet portals is addressed to the cognitive sphere while information from social networks and TV touches the emotional sphere. The profiles of the Internet sources and the press are statistically identical. This result is primarily due to the coincidence of ideas about a qualified approach in the processing and presentation of information through the media of different generations. There are certain differences referred to a faster broadcast of Internet information and the ability to transform a user's thinking and behaviour.

The categories of consciousness that mediate young people's understanding of information from different media are identical in their content. The representatives of the generation $\mathrm{Z}$ assess the information positively and empower with the ability to transform the recipients. However, the poorly differentiated content of the categories and the simplicity of their internal organization prove that the parameters of information are very little understood by young people. That is the reason they do not correspond to a specific type of media. In practice, it means that information from different sources has the same level of influence. Secondly, there is a necessity to teach to analyze information creating the «zone of proximal development». That may be possible by raising up a habit of asking and answering questions, e.g. "Who is the source?», (C) Medvedskaia Elena

DOI (article): https://doi.org/10.32626/2227-6246.2021-53.173-190 
"What are the purposes?», "What is the position?», "What are the pros and cons?», "How does this position correlate with mine?». Third, such habits are significant both on a social level (being an effective way of countering possible organized destructive attacks on the mass consciousness) and individual (acting as a defense against possible cyber crimes).

\section{Literature}

Айсина P.M. Психологическая безопасность интернет-пользователей: анализ современных исследований. Вестник Омского университета. Серия "Психология», 2019, 1, 28-38. DOI 10.25513/24106344.2019.1.28-38.

Горбунов К.Г. Противодействие террористической пропаганде в Интернете. Вестник Олского университета. Серия «Психология», 2016, 2, 23-35.

Дробышева Т.В., Емельянова Т.П., Дробышева М.М., Шмидт Д.Ф. Обсуждение проблемы безработицы в связи с пенсионной реформой в печатных СМИ и в Интернете. Вестник Университета Российской академии образования, 2019, 3, 49-54.

Кириллов И.П., Соловьева Д.А. Психологическая безопасность детей дошкольного возраста при работе с компьютером и интернет-средой. Вестник практической психологии образования, 2020, 17 (1), 80-84.

Криницкий В.А. Политическая пропаганда экстремизма как средство манипулятивного воздействия на молодежь. Гуманитарные, социально-эконолические и общественные науки, 2019, 11, 66-69. DOI 10.23672/SAE.2019.11.41484.

Онуфрієва Л.А., Дідик Н.М., Чеканська О.М. Психологічні особливості використання студентами інтернет-простору. Інформаційні технологї̈ і засоби навчання, 2019, 74 (6), 250-265.

Петренко В.Ф. Основы психосемантики. Санкт-Петербург : Питер, 2005. $480 \mathrm{c.}$

Салихов А.М., Краснощеченко И.Л. Манипуляция сознанием: как снизить риски экстремистских влияний на молодежь. Прикладная юридическая психология, 2020, 2 (51), 15-23. DOI 10.33463/20728336.2020.2(51).015-0123.

Чусавитина Г.Н., Давлеткиреева Л.З., Новикова Т.В. Анализ современного состояния исследования проблемы формирования у студентов университета устойчивости к технологиям негативного инфор-

(C) Medvedskaia Elena

DOI (article): https://doi.org/10.32626/2227-6246.2021-53.173-190 
DOI: https://doi.org/10.32626/2227-6246.2021-53

2021. випУск 53

мационно-психологического воздействия в сети интернет. Совреленные наукоелкие технологии, 2016, 11 (2), 397-400.

Osgood, C.E., Suci, G., \& Tannenbaum, P. The measurement of meaning. Chicago and London : University of Illinois Press, 1957. 342 p.

Zhang, J., Carpenter, D., \& Ko, M. Online astroturfing: A theoretical perspective. Proceedings of the Nineteenth Americas Conference on Information Systems, August 15-17, 2013. Chicago, Illinois. URL : https://www.researchgate.net/profile/Darrell_Carpenter/publication/286729041.

\section{References}

Aisina, R.M. (2019). Psikhologicheskaia bezopasnost internet-polzovatelei: analiz sovremennykh issledovanii [Psychological safety of Internet users: analysis of modern research]. Vestnik Omskogo universiteta. Seriia «Psikhologiia»-Herald of Omsk University. Series «Psychology», 1, 28-38. DOI 10.25513/2410-6344.2019.1.28-38 [in Russian].

Gorbunov, K.G. (2016). Protivodeistviie terroristicheskoi propagande v Internete [Countering terrorist propaganda on the Internet]. Vestnik Omskogo universiteta. Seriia "Psikhologiia» - Herald of Omsk University. Series "Psychology», 2, 23-35 [in Russian].

Drobysheva, T.V., Emelianova, T.P., Drobysheva, M.M., \& Shmidt, D.F. (2019). Obsuzhdeniie problemy bezrabotitsy $\mathrm{v}$ sviazi s pensionnoi reformoi v pechatnykh SMI i v Internete [Discussion of the problem of unemployment in connection with the pension reform in the print media and on the Internet]. Vestnik Universiteta Rossiiskoi akademii obrazovaniia - Bulletin of University of Russian Academy of Education, 3, 49-54 [in Russian].

Kirillov, I.P., \& Solovieva, D.A. (2020). Psikhologicheskaia bezopasnost detei doshkolnogo vozrasta pri rabote s kompiuterom i internet-sredoi [Psychological safety of preschool children when working with a computer and the Internet environment]. Vestnik prakticheskoi psikhologii obrazovaniia - Bulletin of practical psychology of education, 17 (1), 80-84 [in Russian].

Krinitskii, V.A. (2019). Politicheskaia propaganda ekstremizma kak sredstvo manipuliativnogo vozdeistviia na molodezh [Political propaganda of extremism as a means of manipulative influence on youth]. Gumanitarnyie, sotsialno-ekonomicheskiie i obshchestvennyie naukiHumanities, socio-economic and social sciences, 11, 66-69 [in Russian].

Onufrieva, L.A., Didyk, N.M., \& Chekanska, O.M. (2019). Psykholohichni osoblyvosti vykorystannia studentamy internet-prostoru [Psycho-

(C) Medvedskaia Elena

DOI (article): https://doi.org/10.32626/2227-6246.2021-53.173-190 
DOI: https://doi.org/10.32626/2227-6246.2021-53

2021. ВИПУСК 53

logical characteristics of using Internet space by students]. Informatsiini tekhnolohii $i$ zasoby navchannia - Information technologies and teaching aids, 74 (6), 250-265 [in Ukrainian].

Petrenko, V.F. (2005). Osnovy psikhosemantiki [Basics of psychosemantics]. Sankt-Peterburg : Piter [in Russian].

Salikhov, A.M., \& Krasnoshchechenko, I.L. (2020). Manipuliatsiia soznaniiem: kak snizit riski ekstremistskikh vliianii na molodezh [Consciousness manipulation: how to reduce the risks of extremist influences on youth]. Prikladnaia yuridicheskaia psikhologiia - Applied Legal Psychology, 2 (51), 15-23. DOI 10.33463/2072-8336.2020.2(51). 015-0123 [in Russian].

Chusavitina, G.N., Davletkireieva, L.Z., \& Novikova, T.V. (2016). Analiz sovremennogo sostoianiia issledovaniia problemy formirovaniia $u$ studentov universiteta ustoichivosti $\mathrm{k}$ tekhnologiiam negativnogo informatsionno-psikhologicheskogo vozdeistviia v seti internet [Analysis of the current state of research on the formation of university students' resistance to technologies of negative information and psychological impact on the Internet]. Sovremennyie naukoemkiie tekhnologii - Modern high technologies, 22 (2), 397-400 [in Russian].

Osgood, C.E., Suci, G., \& Tannenbaum, P. (1957). The measurement of meaning. Chicago and London : University of Illinois Press.

Zhang, J., Carpenter, D., \& Ko, M. (2013). Online astroturfing: A theoretical perspective. Proceedings of the Nineteenth Americas Conference on Information Systems, August 15-17, 2013. Chicago, Illinois. Retrieved from https://www.researchgate.net/profile/Darrell_Carpenter/ publication/286729041.

\section{Медведська Олена. Особливості розуміння молодими людьми новинної інформачії з різних типів зМК}

\section{АНОТАЦІЯ}

Mета статmi - встановити специфіку оцінки та розуміння молодими людьми інформації про поточні події в країні та світі, одержуваної з різних ЗМК (новинні інтернет-портали, сочіальні мережі, телевізійні передачі, періодичні друковані видання).

Методи. Дослідження здійснено на вибірці студентів у віці від 17 до 23 років (дівчата, $n=120$ і юнаки, $n=80$ ). Емпіричне дослідження було спрямоване на вирішення трьох завдань. Перше - побудова ієрархії типів ЗМК за двома критеріями (частота звернення до джерела і ступінь довіри до нього). Вирішувалося це завдання за допомогою методики ран-

(C) Medvedskaia Elena

DOI (article): https://doi.org/10.32626/2227-6246.2021-53.173-190 
DOI: https://doi.org/10.32626/2227-6246.2021-53

2021. випуск 53

жування і кореляційного аналізу отриманих даних. Друге - аналіз уявлень молодих людей про характеристики інформації, що транслюється різними типами ЗМК. Для їх вивчення був використаний авторський варіант семантичного диреренціала. Третє завдання - моделювання категорій свідомості, що опосередковують розуміння молодими людьми інформації з різних типів ЗМК; здійснювалася за допомогою факторизації даних семантичного диреренціала.

Результати дослідження. Установлено, що максимальний ступінь довіри молоді люди демонструють щодо інформації про поточні події, яка отримується з інтернет-порталів, сочіальних мереж, а також неформального спілкування. Мінімально вони довіряють повідомленням від представників адміністрації, а також від телебачення та друкованих видань. Порівняльний аналіз профрілів оцінок характеристик інформації для різних типів зМК (інтернет-портали, соціальні мережі, телебачення і газети) виявив між ними статистично достовірні відмінності $(p \leq 0,01)$, за винятком інформачії інтернет-порталів і друкованих видань. У результаті факторного аналізу зіставлено різну кількість категорій, які опосередковують розуміння інформації з різних типів ЗМК, що демонструє вищу когнітивну складність свідомості молодих людей у срері цифрових медіа. Зміст трьох провідних категорій для різних типів медіа виявився фрактично ідентичним.

Висновки. Виявлено прямий взаємозв'язок частоти звернення до інформаційного джерела і довіри до змісту повідомлення. У молодих людей присутній високий ступінь довіри до неофіційних джерел інформації і низький - до офріційних. В уявленнях молодих людей інформація з новинних інтернет-порталів переважно впливає на їх когнітивну сферу, а із соціальних мереж і ТБ - на емоційну. Загальним для новин із циррових $i$ друкованих медіа є кваліфікований підхід до їх створення. Недиференційованість змісту категорій, що опосередковують розуміння інформації $з$ різних типів зМк, доводить їх малоусвідомлюваний характер і актуальність зусиль із розвитку самостійності й критичності мислення молодих людей.

Ключові слова: засоби масової комунікації (ЗМК), інформація, молоді люди, ступінь довіри, категорії свідомості.

Медведская Елена. Особенности понимания молодыми людьми новостной информации из разных типов СМК

(C) Medvedskaia Elena

DOI (article): https://doi.org/10.32626/2227-6246.2021-53.173-190 


\section{АННОТАЦИЯ}

Цель статьи - установить специфику оценки и понимания молодыми людьми информации о текущих событиях в стране и мире, получаемой из разных СМК (новостные интернет-порталы, социальные сети, телевизионные передачи, периодические печатные издания).

Методы. Исследование осуществлялось на выборке студентов в возрасте от 17 до 23 лет (девушки, $n=120$ и юноши, $n=80$ ). Эмпирическое исследование было направлено на решение трех задач. Первая - построение иерархии типов СМК по двум критериям (частота обращения к источнику и степень доверия к нему). Решалась данная задача посредством методики ранжирования и корреляционного анализа полученных данных. Вторая - анализ представлений молодых людей о характеристиках информации, транслируемой разными типами СМК. Для их изучения был использован авторский вариант семантического дифрреренциала. Третья задача - моделирование категорий сознания, опосредующих понимание молодыми людьми информации из разных типов СМК; осуществлялась посредством фракторизации данных семантического дирореренциала.

Результаты исследования. Установлено, что максимальную степень доверия молодые люди демонстрируют по отношению к информации о текущих событиях, получаемой из интернет-порталов, социальных сетей, а также неформального общения. Минимально они доверяют сообщениям от представителей администрации, а также от телевидения и печатных изданий. Сравнительный анализ профилей оценок характеристик информации для разных типов СМК (интернет-порталы, социальные сети, телевидение и газеты) выявил между ними статистически достоверные различия $(p \leq 0,01)$, за исключением информации интернет-порталов и печатных изданий. В итоге факторного анализа установлено различное количество категорий, опосредующих понимание информации из разных типов СМК, что демонстрирует более высокую когнитивную сложность сознания молодых людей в области цифровых медиа. Содержание трех ведущих категорий для разных типов медиа оказалось фактически идентичным.

Выводы. Выявлена прямая взаимосвязь частоты обращения к информационному источнику и доверия к содержанию сообщения. У молодых людей присутствует высокая степень доверия к неофициальным источникам информации и низкая - к официальным. В представлениях

(C) Medvedskaia Elena

DOI (article): https://doi.org/10.32626/2227-6246.2021-53.173-190 
DOI: https://doi.org/10.32626/2227-6246.2021-53

2021. випУСК 53

молодых людей информация из новостных интернет-порталов преимущественно оказывает воздействие на их когнитивную среру, а из социальных сетей и ТВ - на эмоциональную. Общим для новостей из цифровых и печатных медиа является квалифицированный подход к их созданию. Недифрференцированность содержания категорий, опосредующих понимание информации из разных типов СМК, доказывает их малоосознаваемый характер и актуальность усилий по развитию самостоятельности и критичности мышления молодых людей.

Ключевые слова: средства массовой коммуникации (СМК), информация, молодые люди, степень доверия, категории сознания.

Original manuscript received March 30, 2021 Revised manuscript accepted May 14, 2021 